JURNAL SEHAT MASADA VOLUME XVI NOMOR $1 \quad$ Januari $2022 \quad$ ISSN : 1979-2344

\title{
MANFAAT ASAM FOLAT BAGI IBU HAMIL DAN JANIN
}

Literature Review

\author{
Atika Zahria Arisanti ${ }^{1)}$, Melly Lupita Sari ${ }^{2}$ \\ ${ }^{1}$ Dosen Program Studi Sarjana dan Pendidikan Profesi Bidan Universitas Islam Sultan Agung \\ Semarang \\ ${ }^{2}$ Mahasiswa Program Studi Sarjana Kebidanan Fakultas Kedokteran \\ Universitas Islam Sultan Agung Semarang \\ 1atika.zahria@unissula.ac.id \\ ${ }^{2}$ Mellylupita1@gmail.com
}

\begin{abstract}
ABSTRAK
Asam folat adalah bentuk sintetis dari folat yang merupakan salah satu bagian dari vitamin B, yang memiliki pengaruh baik pada kesehatan ibu hamil.dalam perkembangan otak janin dan pembentukan hemoglobin. Asam folat memiliki manfaat banayk terhadap kehamilan yaitu pembentukan hemoglobin sehingga mengurangi penderita anemia pada saat hamil,asam folat juga bisa bermanfaat dalam pertumbuhan otak janin. Jika ibu hamil yang kurang mengonsumsi asam folat sangat mudah terkena anemia, menghambat perkembangan janin. Artikel ini dicari pada google scholardengan kata kunci "ibu hamil,"kegunaan asam folat". Dan saya menemukan 10 artikel yang relavan dari artkel tahun 2011-2021.
\end{abstract}

Keyword : Asam folat, kehamilan, ibu hamil, janin, manfaat asam folat

\section{PENDAHULUAN}

Pemberian asam folat pada ibu hamil diketahui untuk mencegah terjadinya neural tube defect (cacat bawaan yang timbul akibat tidak sempurnanya penutupan neural tube (tabung saraf) selama pertumbuhan embrional), terutama spina bifida dan anenchepalus pada fetus. Asam folat diberikan kepada ibu hamil secara adekuat untuk proteksi maksimal terhadap kejadian neural tube defect. 1 Neural tube defect adalah prevalensi anomali kongenital terbanyak kedua setelah malformasi jantung di Amerika Serikat, dan berasosiasi terhadap morbiditas dan mortalitas.2 Anak-anak dengan neural tube defect berasosiasi dengan anomali perkembangan otak yang lebih berat. Banyaknya anomali perkembangan otak yang berat berasosiasi dengan buruknya neurobehavior yang diketahui dari inteligensia, kemampuan akademis, dan perilaku beradaptasi. 
Asam folat adalah bentuk sintetis dari folat yang merupakan salah satu bagian dari vitamin B, yaitu B9 (Goetzl, 2017). Defisiensi asam folat merupakan kadar asam folat di bawah normal, yaitu folat serum $<3 \mathrm{ng} / \mathrm{ml}$ dan folat eritrosit $<$ $130 \mathrm{ng} / \mathrm{mL}$ (Mayes, 2007). Defisiensi folat ini dapat terjadi karena akibat langsung dari kurangnya konsumsi harian, absorbsi yang buruk dari folat yang dimakan serta peningkatan penggunaan (misalnya saat beraktivitas fisik, kehamilan); dapat pula disebabkan oleh kondisi liver patologis dan gangguan metabolisme folat oleh karena defek genetik atau interaksi obat (Scaglione, 2014).

Dampak kekurangan asam folat terhadap ibu hamil salah satunya adalah anemia. Anemia merupakan masalah yang sering terjadi pada ibu hamil. Prevalensi anemia pada ibu hamil sebesar $37,1 \%$ (Riskesdas 2013) dan angka kematian ibu adalah 359/100.000 kelahiran hidup (SDKI 2012).

Penyebab anemia terutama adalah kekurangan zat gizi yang berperan dalam pembentukan hemoglobin, yaitu protein, besi, vitamin $\mathrm{B} 12$, vitamin $\mathrm{C}$ dan asam folat. Vitamin B12 dibutuhkan untuk mengaktifkan asam folat dan metabolisme sel, terutama sel-sel saluran cerna, sumsum tulang dan jaringan syaraf. Asam folat berperan dalam metabolisme asam amino yang diperlukan dalam pembentukan sel darah merah (Mahenaz \& Ismail 2011). Penelitian Li Wen-Xing (2016), mengungkapkan fungsi asam folat dapat meningkatkan enzim alanin aminotransferase (ALT), asparat transaminase (AST), dan gutamyl (GGT) yang penting untuk metabolism di hati.

Kekurangan vitamin B12 dan asam folat selama kehamilan berhubungan dengan peningkatan risiko kelahiran prematur, berat bayi lahir rendah dan terganggunya pertumbuhan janin (Charles et al. 2005). Selain itu kekurangan B12 dapat menyebabkan kesemutan, gangguan penglihatan, alzheimer dan demensia (Rathod et al. 2016). Sebanyak $80 \%$ ibu dengan kadar asam folat $>27,00 \mathrm{nmol} / \mathrm{L}$ melahirkan bayi dengan ukuran lingkar kepala normal, sementara ibu dengan kadar asam folat rendah $<27,00 \mathrm{nmol} / \mathrm{L}$ hanya 15,4\% (Darwanti \& Antini 2011).

Menurut WHO jika seorang ibu didiagnosis dengan anemia dalam pengaturan klinis, ibu harus mengonsumsi zat besi (120mg/ hari) dan asam folat (400g atau 0,4mg / hari) suplementasi sampai konsentrasi hemoglobinnya naik menjadi normal $(2,21)$. Kemudian ibu dapat beralih ke dosis antenatal standar (30-60 mg/hari zat besi dan Asam folat: $400 \mathrm{~g}$ atau $0,4 \mathrm{mg} / \mathrm{hari}$ ) untuk mencegah 
kekambuhan anemia.(World Health Organization et al., 2012)

\section{METODE PENELITIAN}

Dalam mencari artikel cara yang digunakan dalam bahasa indoneisa dan bahasa inggris yang relavan dengan topik. Pencarian dilakukan dengan database antara lain Google Scholer. Keyword yang digunakan adalah "kegunaan asam folat" dan "ibu hamil". Artikel yang diperoleh di review untuk memilih artikel yang sesuai dengan criteria dan didapatkan 10 artikel nasional yang selanjutnya akan di review.

\section{HASIL DAN PEMBAHASAN}

Penelitian pertama dilakukan oleh Eka Puspita Astriningrum, dkk (2017) di SDT 2014, mencakup 497 kabupaten/kota yang tersebar di 33 provinsi. Dengan metode desain cross-sectional study. Data konsumsi pangan diperoleh dengan metode recall 24 jam. Subjek penelitian ini adalah 606 ibu hamil umur 14-49 tahun. Asupan asam folat, vitamin B12 dan vitamin $\mathrm{C}$ dianalisis menggunakan daftar komposisi pangan dari Tabel Komposisi Bahan Makanan, perangkat lunak nutrisurvey, informasi kandungan gizi dari produk kemasan berlabel dan Tabel Bahan Makanan Departemen Pertanian Amerika Serikat.
Hasil penelitian menunjukkan ratarata asupan vitamin asam folat, vitamin B12 dan vitamin $\mathrm{C}$ berturut-turut $152,4 \pm 98,7 \mathrm{~g} / \mathrm{hari}, 3,4 \pm 7,1 \mathrm{~g} / \mathrm{hari}$ dan $62,3 \pm 72,7 \mathrm{mg} /$ hari. Prevalensi ibu hamil yang tergolong defisiensi tingkat berat adalah $88,3 \%, 34,5 \%$ dan $46,9 \%$, masingmasing untuk asam folat, vitamin B12 dan C. Terdapat perbedaan $(\mathrm{p}<0,05)$ asupan vitamin B12 berdasarkan wilayah, pendidikan dan status ekonomi, dimana asupan vitamin B12 wilayah perkotaan.(Astriningrum et al., 2017)

Jurnal yang lain menurut Juandra darwati, dkk (2011) di Kabupaten Karawang. Hasil analisa univariat menunjukkan bahwa 72,2 persen ibu hamil dengan kadar asam folat rendah, yang mengalami anemia sebanyak 38,9\%. Hasil analisa bivariat menunjukkan ada hubungan yang bermakna antara kadar asam folat dengan ukuran lingkar kepala janin $(\mathrm{P}=0,022)$, dan antara kadar haemoglobin dengan ukuran lingkar kepala janin $(\mathrm{P}=0,025)$, besarnya pengaruh asam folat terhadap ukuran lingkar kepala sebesar 26,7\% dan $\mathrm{Hb}$ sebesar 25,8\%. Sedangkan secara bersama-sama folat dan $\mathrm{Hb}$ berpengaruh sebesar 34,4\%. Jadi, ada hubungan antara asam folat dan kadar hemoglobin terhadap pertumbuhan otak janin. Diperlukan upaya menurunkan anemia dengan pemantauan konsumsi $\mathrm{Fe}$ 
pada ibu hamil dan peningkatan pemahaman ibu hamil tentang pentingnya asam folat bagi janinnya.(Jundra Darwanty, 2011)

Penelitian yang ketiga adalah dari Wici Septiyeni, dkk (2016) dikabupaten padang pariman. Dengan menggunakan metode Penelitian ini merupakan cross sectional study pada 59 ibu hamil di Kabupaten Padang Pariaman. Pengumpulan data dilakukan dengan wawancara dan pengukuran berat badan lahir. Analisis statistik yang digunakan adalah uji korelasi Spearman. Hasil penelitian ini yaitu rata-rata umur ibu hamil sebesar 26,5424 tahun. Rata-rata berat badan lahir 3181,36 gram dan rata-rata tinggi badan ibu adalah 153,8305 cm. Rata-rata konsumsi asam folat subjek penelitian adalah 341,9525 ug, zink 5,0727 mg dan vitamin A 688,9300 RE. Hasil analisis menunjukkan tidak terdapat hubungan yang bermakna antara asupan asam folat dan berat badan lahir ( $p>0,05$ ), asupan zink dan berat badan $(p>0,05)$ dan asupan vitamin $A$ dan berat badan lahir ( $p>0,05)$. Kesimpulan penelitian ini adalah bahwa tidak ada hubungan antara asupan asam folat, zink dan vitamin A ibu hamil trimester III terhadap berat badan lahir. (Septiyeni et al., 2016)

Artikel yang ke empat merupakan penelitian dari Evis Ritawani Hasibuan (2017) di Klinik Pratama Sarinah. Dengan menggunakan metode penelitian analitik kuantitatif dengan desain cross sectional, populasi yaitu ibu hamil sebanyak 126 orang, dengan sampel 56 orang. Hasil penelitian dari 56 responden, 34 (60,7\%)responden berpengetahuan kurang dan $23(74,2 \%)$ responden bersikap negatif dalam mengonsumsi asam folat. Berdasarkan analisa uji chi-square didapatkan $p$ value 0,043 yang artinya $p<$ $\alpha 0,05$,ada hubungan antara pengetahuan dengan sikap ibu hamil dalam mengonsumsi asam folat. Diharapkan ibu hamil agar lebih aktif dalam mencari informasi dengan cara bertanya, dan bagi nakes dapat menyelipkan informasi tentang asam folat ditiap kunjung ibu hamil.(Hasibuan, 2017)

Pada penelitian ke lima dari jean Christy ade putri (2021) di Klinik Hayyat Medical and Wellness Center Mamuju. Dengan menggunakan metode penelitian deskriptif dan pengambilan sample dengan menggunakan total sampling. Populasi penelitian ini adalah semua ibu hamil yang dating memerikasakan kehamilannya di Klinik Hayyat Medical and Wellness Center Mamuju 56 responden. Pengumpulan data yang digunakan yaitu koesioner. Dari hasil penelitian ini yaitu didapatkan berdsarkan tingkat berpengetahuan baik sebanyak 15 orang $(26,79 \%)$, berpengetahuan cukup sebanyak 32 orang $(57,14 \%)$, dan berpengetahuan kurang sebnyak 9 orang $(16,07 \%)$. Berdasarkan hasil penelitian dan pembahasan yang telah diuraikan, maka 
dapat di simpulkan bahwa tingkat pengetahuan pasien ibu hamil tentang manfaat asam folat di klinik hayyat and welness center kabupaten mamuju dalam kategori berpengetahuan cukup sebanyak 32 orang (57.14\%).(Juli et al., 2021)

Jurnal yang ke enam menurut Khairani (2021) di Puskesmas Patumbak. Penelitian ini menggunakan metode deskriptif dengan rancangan crossectional. Populasi pada penelitian ini yaitu ibu hamil trimester III dan jumlah sampel pada penelitian ini sebanyak 18 responden. Pengambilan sample secara simple random sampling. Hasil analisis univariat menunjukkan bahwa $72,2 \%$ ibu hamil dengan kdar asam folat rendah, yang mengalami anemia sebanyak 38,9\%. Hasil analisa bivariat menunjukkan ada hubungan yang bermakna antara kadar asam folat dengan ukuran lingkar kepala janin $(\mathrm{P}=0,022)$, dan antara kadar haemoglobin dengan ukuran lingkar kepala janin $(\mathrm{P}=0,025)$, besarnya pengaruh asam folat terhadap ukuran lingkar kepala sebesar 26,7\% dan $\mathrm{Hb}$ sebesar 25,8\%. Sedangkan secara bersama sama folat dan $\mathrm{Hb}$ berpengaruh sebesar 34,4\%. Kesimpulan penelitain ini Ada hubungan antara asam folat dan kadar hemoglobin terhadap pertumbuhan otak janin. Diperlukan upaya menurunkan anemia dengan pemantauan konsumsi Fe pada ibu hamil dan peningkatan pemahaman ibu hamil tentang pentingnya asam folat bagi janinnya.

(Medan, 2021)

Penelitian ke tujuh dari Wiwit Hidayah dan Tri Anasari (2010) di Desa Pangeraji Kecamatan Cilongok Kabupaten Banyumas. Metode dalam penelitian ini menggunakan studi deskriptif dengan desain case control dan pendekatan retrospektif, Subjek pada penelitian ini seluruh ibu yang pernah hamil dan melahirkan yang mendapatkan 90 tablet zat besi sebanyak 127 orang, masingmasing di ambil sebanyak 56 ibu yang mengalami anemia dan dan 56 ibu yang tidak mengalami anemia. Hasil dari jurnal ini berdasarkan penelitian yang telah dilakukan diketahui bahwa ibu yang mengalami anemia dan tidak patuh mengonsumsi tablet $\mathrm{Fe}(62,5 \%)$ lebih banyak dibandingkan yang patuh mengonsumsi tablet $\mathrm{Fe}(37,5 \%)$. Ibu yang tidak mengalami anemia dan patuh mengonsumsi tablet $\mathrm{Fe}(64,3 \%)$ lebih banyak dibandingkan yang tidak patuh (35,7\%). Hasil uji statistik dengan menggunakan uji Chi Square diperoleh ada hubungan antara kepatuhan ibu hamil mengkonsumsi tablet $\mathrm{Fe}$ dengan kejadian anemia di Desa Pageraji Kecamatan Cilongok Kabupaten Banyumas dengan nilai $\mathrm{p}=0,005$. Artinya semakin baik 
kepatuhan ibu dalam mengkonsumsi tablet $\mathrm{Fe}$ maka semakin rendah resiko ibu mengalami anemia (Anasari, 2012).

Penelitian berikutnya menurut Sri rahayu, dkk (2019) di Jawa Barat. Penelitian ini menggunakan metode deskriptif dengan desain penilitan cross sectional dan sampel dilipih menggunakan metode total sampling dari penelitian Academic Leadership Grant (ALG). Subjek dari penelitian ini yaitu ibu hamil trimester 1 sebanyak 176 responden yang berdomisili di Kota Sukabumi, Kabupaten Cirebon, Kota Bandung, dan Kota Cimahi yang di ambil pada periode Juli 2016Februari 2017. Hasil dari penelitian ini Sebagian besar responden yang asupan asam folatnya tidak terpenuhi yaitu sebesar 97,2\% dan asupan sengnya tidak terpenuhi yaitu sebesar $96 \%$ dengan rerata asupan asam folat $163 \mathrm{mg} /$ hari dan rerata asupan seng 5,1 mg/hari. Jadi Sebagian besar responden termasuk dalam kategori asupan asam folat dan seng yang tidak terpenuhi dengan rerata dibawah anjuran Angka Kebutuhan Gizi (AKG) ibu hamil.(Rahayu et al., 2019)

Penelitian yang dilakukan oleh Baul Setyawati (2013) di Puskesmas Tanggung Harjo Ksbupaten Grobogan. Penelitian ini dilakukan secara observasional dengan rancangan cross sectional di puskesmas tanggungharjo kabupaten grobogan.
Populasi berjumplah 46 subyek dari ibu hamil trimester III dimana 23 ibu hamil anemia dan 23 ibu hamil tidak anemia yang berusia 20-35 tahun dan dipilih menggunakan metode cyanmethemoglobin. Pada analisis ini didapatkan nilai menian (minimummaksimum) untuk asupan protein adalah $37,4(29,4-67,8) \mathrm{gr} /$ hari dari kelompok anemia dan 43,7 (29,4-67,8) gr/ haridari kelompok anemia, untuk asupan zat besi adalah $6,9 \quad(3,5-48,0) \mathrm{mg} /$ hari dari kelompok anemia dan $7,00 \mu \mathrm{g} /$ hari dri kelompok anemia serta untuk asupan vitamin B12 adalah 1,1 $(0,05-3,5) \mu \mathrm{g} /$ hari dari kelompok anemi dan 1,9 (0,8-3,7) $\mu \mathrm{g} /$ hari dari kelompok tidak anemi. Nilai rerata asupan asam folat pada kelompok anemia adalah 4,9 $\mu \mathrm{g} /$ hari dan standart deviasi (SD) 6,52 gr, sedangkan pada kelompok tidak anemia adlah 6,06 $\mu \mathrm{g} /$ hari dan standart deviasi (SD) 7,11gr. Jadi dapat perbedaan bermakna asupan protein (p 0.032) dan vitamin B12 (p 0,03) antara ibu hamil trimester III anemia dan tidak anemia serta tidak terdapat perbedaan bermakna asupan zat besi $(p=0,75)$ dan asam folat $(p=0,56)$ antara ibu hamil trimester III anemia dan tidak anemia di puskesmas tanggung harjo kabupaten grobogan. Pada artikel ini dari hasil analisis data asupan yang telah dilakukan kejadian anemia pada ibu hamil trimester 
III disebabkan defisiensi vitamin B12 yang sering di sebut anemia megaloblastik.(Setyawati. B, 2013)

Jurnal ke sepuluh menurut rizki nadya putri, dkk (2019) dikecamatan jatinagor. Metode yang digunakan ialah analitik korelatif dengan pendekatan crossectional. Populasi 210 ibu di Kecamatan Jatinangor. Teknik pengambilan sampel accidental sampling dengan sampel 66 ibu hamil. Pengambilan data menggunakan metode food record selama 3 hari. Hasil dari dianalisis menggunakan uji koefisien kontingensi menunjukkan tidak ada hubungan antara usia $(p=0,91)$, paritas $(p=0,42)$, pendidikan $(\mathrm{p}=0,96)$, status gizi $(0,41)$, zat besi $(0,76)$, asam folat $(0,94)$ dan vitamin C $(0,92)$ dengan status anemia. Kesimpulan dari penelitian ini tidak $\mathrm{k}$ ada hubungan antara karakteristik ibu, asupan zat besi, asam folat dan Vitamin $\mathrm{C}$ dengan status anemia ibu hamil.(Putri et al., 2019)

\section{DISKUSI}

Dari hasil literature review yang telah didapatkan semua artikel menjelaskan tentang kegunaan asam folat kepada ibu hamil semua jurnal menjelaskan bahwa asam folat memiliki pengaruh penting pada ibu hamil dan janin.
Asam folat mempunyai peran yang sangat vital dalam pencegahan cacat bawaan. Selain itu juga berperan dalam neuro kognitif (Sulhub, et all, 2000). Selain itu defisiensi folat menyebabkan kelainan neurologik, psikologik dan metabolisme karbon. Salah satu cara untuk mendeteksi kekurangan asam folat dapat dilihat dengan pertumbuhan otak janin selama kehamilan yang dapat dilihat dari besarnya lingkar kepala BBL.

Kekurangan asam folat dalam kehamilan akan menyebabkan gangguan pematangan inti eritrosit, sehingga muncul sel darah merah dengan bentuk dan ukuran abnormal yang disebut sebagai Anemia megaloblastik, lebih jauh gangguan metabolisme asam folat akan menyebabkan gangguan replikasi DNA dan proses pembelahan sel, dan ini akan mempengarui kerja seluruh sel tubuh, termasuk dalam metabolisme besi. Sehingga kita menemukan kenyataan bahwa defisiensi folat dan defisiensi besi secara bersamaan.Willis mengatakan bahwa folat dibutuhkan sebagai pencegahan anemia pada saat kehamilan. Kadar asam folat dan haemoglobin ibu hamil secara bersamasama akan mempengaruhi pertumbuhan janin (Juanda, et all, 2011).

Proses pertumbuhan sel neuron otak terjadi pada minggu ke-20 hingga ke-36, 
dan disempurnakan hingga bayi berusia dua tahun. Menurut Arif Achmad, dokter gizi medik, pertumbuhan massa sel otak ini dimulai semenjak janin di dalam kandungan hingga menjadi balita. Sel otak sangat membutuhkan makanan bergizi untuk membantu agar dia dapat berkembang dengan baik. Meskipun masa otak janin hanya sekitar $16 \%$ dari tubuhnya, dibandingkan dengan organ tubuh lain, otak paling banyak memerlukan energi (lebih dari 70\%) untuk proses tumbuh kembangnya janin (Juanda, et all, 2011).

Asam folat memiliki peranan penting dalam pertumbuhan janin. Asam folat sangat penting peranannya dalam pembetukan hemoglobin dan perkembangan otak pada janin. Jadi dengan kesadaran ibu hamil dalam pengkonsumsian asam folat dalam vitamin B12 sangat membantu penstabilan tubuh. Karena ibu hamil sangat rentan mengalami anemia janin (Juanda, et all, 2011).

\section{KESIMPULAN}

Pemberian asam folat sangat berpengaruh padan kebutuhan nutrisi ibu hamil. Asam folat ini sangat berpengaruh untuk menjaga kesehatan kehamilan. Dimana fungsinya sebagai pembentuk hemoglobin untuk mengurangi anemia ibu hamil dan mencegah cacat lahir pada otak janin dan syaraf bayi.

Pengetahuan ibu hamil tentang pengaruh asam folat pada kehamilan masih sangat jarang diketahui. Padahal asam folat memiliki efek baik terhadap kehamilan dan asam folat juga bisa dikatakan alternative penambah darah pada ibu hamil.

Namun dengan melihat beberapa artikel tersebut kita dapat melihat bukti kelebihan dari asam folat.

\section{DAFTAR PUSTAKA}

Jundra Darwanty, Ari Antini. (2011).'Kontribusi Asam Folat Dan Kadar Haemoglobin Pada Ibu Hamil Terhadap Pertumbuhan Otak Janin Di Kabupaten Karawang Tahun 2011', Prodi Kebidanan Karawang Poltekkes Kemenkes Bandung.

Eka Puspita Astriningrum, dkk. (2017). 'Asupan Asam Folat, Vitamin B12 Dan Vitamin C Pada Ibu Hamil Di Indonesia Berdasarkan Studi Diet Total', jurnal Gizi pangan, Volume 12, Nomor 1, Maret 2017.

Wici Septiyeni, dkk. (2016). 'Hubungan Asupan Asam Folat, Zink, dan Vitamin A Ibu Hamil Trimester III terhadap Berat Badan Lahir di Kabupaten Padang Pariaman',jurnal Kesehatan Andalas, vol.5, No.1.

Evis Ritawani Hasibuan. (2017). 'Pengetahuan Dengan Sikap Ibu Hamil Dalam Mengonsumsi Asam Folat', Jurnal Endurance 2 oktober 2017 $(245-2)$ 
Jean Christy Ade Putri. (2021). 'Gambaran Tingkat Pengetahuan Pasien Ibu Hamil Tentang Manfaat Asam Folat Di Klinik Hayyat Medical And Wellness Center Di Mamuju', Jurnal Kesehatan Luwu Raya Vol.10 No.10

Khairani. (2021). 'Kontribusi Asam Folat Dan Kadar Haemoglobin Pada Ibu Hamil Terhadap Pertumbuhan Otak Janin Di Puskesmas Patumbak Tahun 2021', Jurnal Ilmiah Kebidanan, Vol.1, Nomor 2.

Wiwit Hidayah dan Tri Anasari. Hubungan Kepatuhan Ibu Hamil Mengkonsumsi Tablet Fe Dengan Kejadian Anemia Di Desa Pageraji Kecamatan Cilongok Kabupaten Banyumas', Jurnal Ilmiah Kebidanan, Vol. 3 No. 2.
Rahayu, Sri, dkk. (2019). 'Survei Asupan Asam Folat dan Seng pada Ibu Hamil di Jawa Barat', Jurnal Kesehatan Vokasional, Vol. 4 No. 3.

Setyawati, B. (2013). 'Perbedaan Asupan Protein, Zat Besi, Asam Folat, \& Vitamin B12 Antara Ibu Hamil Trimester III Anemia Dan Tidak Anemia Di Puskesmas Tanggungharjo Kabupaten Grobogan. Artikel penelitian : Universitas Diponegoro Semarang.

(Putri et al., 2019). Hubungan antara Karakteristik Ibu, Kecukupan Asupan Zat Besi, Asam Folat dan Vitamin $C$ dengan Status Anemia pada Ibu Hamil di Kecamatan Jatinangor. Jurnal Kesehatan Vokasional, Vol. 4 No. 4.

(World Health Organization et al., 2012). Guideline: Daily iron and folic acid supplementation in pregnant women. Vol 46. 